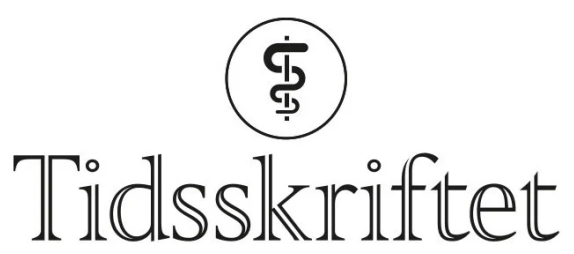

DEN NORSKE LEGEFORENING

\title{
Osteomyelitt i barns kjeve
}

LEDER

JOHANNA ELISABETH RYKKE BERSTAD

jberstad@ous-hf.no

Johanna Elisabeth Rykke Berstad er tannlege, spesialist i oral kirurgi og oral medisin og enhetsleder ved Enhet for tann og kjeve ved Øre-nese-hals-avdelingen ved Oslo universitetssykehus, Rikshospitalet.

Forfatteren har fylt ut ICMJE-skjemaet og oppgir ingen interessekonflikter.

\section{Mandibelen er mer mottakelig for osteomyelitt enn andre ansiktsknokler. Ikke-odontogen osteomyelitt i mandibelen kan bli kronisk. Både infeksjon og autoinflammatoriske prosesser kan ligge bak en slik tilstand.}

Nyland og medarbeidere omtaler i Tidsskriftet fire kasuistikker som belyser en sjelden, men omdiskutert tilstand i mandibelen hos barn: ikke-odontogen osteomyelitt (프). De fire pasientene illustrerer spennvidden fra et godartet forløp med full remisjon til en kronisk residiverende tilstand med mulig utvikling av autoimmunitet. Ingen av de beskrevne tilfellene hadde kjent odontogen årsak, men de hadde symptomer og flere funn forenlige med bakteriell infeksjon. Alle hadde forutgående infeksjoner i øre-nese-hals-området og fikk langvarig antibiotikabehandling. Bakterien Kingella kingae (tidligere Moraxella kingii) er beskrevet som den vanligste årsaken til osteomyelitt hos barn, og sees ofte etter

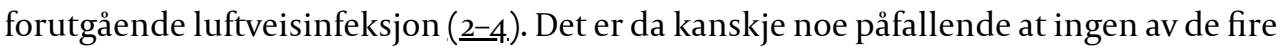
barna fikk påvist K. kingae eller andre Kingella-arter, og at dette ikke er omtalt i diskusjonen. Det er heller ikke anført å ha blitt benyttet andre mikrobiologiske metoder enn dyrkning. Til tross for dette konkluderer forfatterne med at forløpet hos to av pasientene sannsynligvis var mer forenlig med kronisk ikke-bakteriell osteomyelitt enn med infeksjonsutløst osteomyelitt.

En vanlig årsak til osteomyelitt i mandibelen er odontogen infeksjon (5). Ikke-bakteriell osteomyelitt er en utelukkelsesdiagnose og antas å være en autoinflammatorisk tilstand uavhengig av lokalisasjon ( $\underline{6}$ ). Tilstanden rammer hyppigst i barneskolealder, med en antatt årlig insidens på 4 per 1000 ooo barn (7.). I mer uttalt form betegnes tilstanden som kronisk residiverende multifokal osteomyelitt og kan da involvere mandibula, clavicula, vertebrae, pelvis og de lange rørknoklene. 
Etiologien ved ikke-bakteriell osteomyelitt og kronisk residiverende multifokal osteomyelitt er ikke fullt ut forstått. En aktuell teori innebærer at et antigen, f.eks. en mikroorganisme, har trigget en autoimmun reaksjon. Parallellen til sammenhengen mellom infeksjon med bakterien Helicobacter pylori i mageslimhinnen og pernisiøs anemi er nærliggende. H. pylori er ikke bare årsak til peptisk ulcus (ulcus ventriculi og ulcus duodeni) og utvikling av ventrikkelcancer, men også til induksjon av autoimmunitet (ㅁ) Dette kan resultere i atrofisk gastritt og dernest pernisiøs anemi (9.). Når slik autoimmunitet foreligger, er bakterien ofte ikke lenger påvisbar i ventrikkelslimhinnen.

Ved mistanke om osteomyelitt i mandibelen skal odontogen årsak utelukkes først. Dersom odontogen årsak ikke avdekkes, bør pasienten raskt henvises til regional øre-nese-halsavdeling med oral- og kjevekirurgisk kompetanse for videre utredning og diagnostikk. I denne utredningen inngår omfattende klinisk anamnese, radiologiske undersøkelser

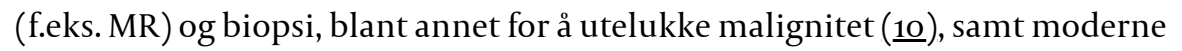
mikrobiologisk diagnostikk som innbefatter PCR-baserte mikrobiologiske teknikker som 16S/18S rRNA-amplifisering og -sekvensering. Metoder som sistnevnte gjøres med steril prosedyre, fortrinnsvis i narkose, og er spesielt viktige dersom pasienten har vært behandlet med antibiotika i forkant. Det er kritisk at utredningen ikke treneres, da det som hos pasient 4 i artikkelen til Nyland og medarbeidere (1) kan avdekkes en bakenforliggende grunntilstand. Malignitet kan til forveksling ligne på osteomyelitt i mandibelen (10).

Forløpet hos barn med ikke-bakteriell osteomyelitt og kronisk residiverende multifokal osteomyelitt er beskrevet som uforutsigbart - fra milde varianter med selvbegrensende forløp til alvorlige forløp med større destruksjoner av benvev (므). Min erfaring med barn med ikke-bakteriell osteomyelitt i mandibelen er at prognosen etter introduksjonen av moderne barnerevmatologisk behandling er adskillig bedre enn tidligere. Det vanlige er nå remisjon, og i mindre grad stadige residiv, mutilerende kirurgi og livsvarige kosmetiske og funksjonelle forandringer.

\section{LITTERATUR}

1. Nyland AN, Nordtveit ES, Bosse FJ et al. Osteomyelitt i underkjeven. Tidsskr Nor Legeforen 2022; 142. doi: 10.4045/tidsskr.21.0478. [CrossRef]

2. Infeksjoner i bein og ledd. Pediatriveileder. Norsk barnelegeforening. Revidert 2021. https://www.helsebiblioteket.no/retningslinjer/akuttveileder-i-pediatri/infeksjoner/infeksjoner-ibein-og-ledd Lest 22.1.2022.

3. Ceroni D, Coulin B et al. Should we investigate osteoarticular infections for Kingella kingae in older-than-expected immunocompetent children? Pediatr Infect Dis J 2020; 39: e57-8. [PubMed] [CrossRef]

4. Wallin D, Kienstra AJ. Not by the red on my chinny chin chin: A case of mandibular osteomyelitis in a 5-year-old girl. J Emerg Med 2016; 50: e219-21. [PubMed][CrossRef]

5. Chow AW. Complications, diagnosis, and treatment of odontogenic infections. UpToDate. https://www.uptodate.com/contents/complications-diagnosis-and-treatment-of-odontogenicinfections Lest 22.12022.

6. Zhao DY, McCann L, Hahn G et al. Chronic nonbacterial osteomyelitis (CNO) and chronic recurrent multifocal osteomyelitis (CRMO). J Transl Autoimmun 2021; 4: 100095. [PubMed][CrossRef]

7. Jansson AF, Grote V. Nonbacterial osteitis in children: data of a German Incidence Surveillance Study. Acta Paediatr 2011; 100: 1150-7. [PubMed][CrossRef]

8. Negrini R, Lisato L, Cavazzini L et al. Monoclonal antibodies for specific immunoperoxidase detection of Campylobacter pylori. Gastroenterology 1989; 96: 414-20. [PubMed][CrossRef] 
9. Desai HG, Gupte PA. Helicobacter pylori link to pernicious anaemia. J Assoc Physicians India 2007; 55: 857-9. [PubMed]

10. Buch K, Thuesen ACB, Brøns C et al. Chronic non-bacterial osteomyelitis: a review. Calcif Tissue Int 2019; 104: 544-53. [PubMed][CrossRef]

Publisert: 14. februar 2022. Tidsskr Nor Legeforen. DOI: 10.4045/tidsskr.22.0039

(C) Tidsskrift for Den norske legeforening 2023. Lastet ned fra tidsskriftet.no 26. april 2023. 